\title{
ANALISIS TEGANGAN TARIK DAN LENTUR SAMBUNGAN ALUMINIUM AA 6061 HASIL PENGELASAN FRICTION STIR WELDING (FSW) MENGGUNAKAN PIN SHOULDER TOOL PERSEGI EMPAT
}

\author{
Muhammad Arsyad Suyuti, Luther Sonda ${ }^{1)}$, Misdar, Raichard Pasau ${ }^{2)}$
}

\begin{abstract}
Abstrak: Penelitian ini bertujuan untuk menganalisa tegangan tarik maksimum dan tegangan lentur yang dihasilkan dari hasil pengelasan friction stir welding. Dalam pengelasan ini meterial yang disambung adalah Aluminium AA 6061. Sedangkan parameter pengelasan friction stir welding yang divariasikan yaitu putaran tool, dan kecepatan pengelasan (feeding). Tool yang digunakan memiliki pin shoulder berbentuk persegi empat dengan ukuran sisi yang sama. Dari hasil uji tarik diperoleh tegangan tarik tertinggi pada putaran $1300 \mathrm{rpm}$ dengan feeding $90 \mathrm{~mm} / \mathrm{min}$ sebesar $160,93 \mathrm{MPa}$ sedangkan tegangan lentur tertinggi diperoleh pada root bending di putaran $1300 \mathrm{rpm}$ dengan feeding $135 \mathrm{~mm} / \mathrm{min}$ sebesar 487,22 MPa. Secara umum kualitas sambungan hasil pengelasan yang terbaik jika ditinjau dari segi tegangan tarik maksimum dan tegangan lentur diperoleh pada putaran rendah yaitu $1300 \mathrm{rpm}$. Namun demikian baik tegangan tarik maksimum maupun tegangan lentur pada daerah sambungan nugget zone dan Thermomechaniically Affected Zone (TMAZ) masih jauh lebih rendah dari pada tegangan tarik maksimum dan tegangan lentur logam induk.
\end{abstract}

Kata kunci: Alumunium AA 6061, feeding, friction stir welding, putaran tool, pin shoulder.

\section{PENDAHULUAN}

Pengelasan merupakan salah satu teknik penyambungan yang banyak digunakan dalam industri manufaktur untuk menyambung beberapa komponen penyusun suatu konstruksi mesin atau konstruksi umum sehingga menjadi satu kesatuan kompleks dan utuh. Banyaknya pemanfaatan pengelasan dalam perakitan (assembly) suatu konstruksi karena, penyambungan pengelasan lebih ringan dari segi berat dibandingkan dengan sambungan paku keling dan baut; tidak ada lubang yang bisa melemahkan penampang las; serta sederhana dari proses pembuatannya sehingga mengurangi biaya produksi lebih murah dan lebih efisien dengan kualitas tinggi. Adapun ruang lingkup pemanfatannya meliputi penyambungan konstruksi jembatan, pesawat, perpipaan, perkapalan, kereta, dsb.

Salah satu jenis pengelasan yang banyak dikembangkan saat ini adalah friction stir welding. FSW merupakan teknik pengelasan dimana pelat disambung dari sumber panas hasil gesekan perkakas berputar (tool) dan permukaan pelat. Prinsip kerja FSW adalah memanfaatkan gesekan dari benda kerja yang berputar terhadap benda kerja yang diam sehingga benda kerja yang diam meleleh dan menjadi tersambung (Pamungkas dkk, 2012).

Perkembangan dunia industri manufaktur saat ini mulai menggunakan material aluminium dalam proses produksi. Hal ini dikarenakan logam aluminium

\footnotetext{
${ }^{1}$ Staf Pengajar Jurusan Teknik Mesin Politeknik Negeri Ujung Pandang

${ }^{2}$ Alumni Jurusan Teknik Mesin Politeknik Negeri Ujung Pandang
} 
memiliki sifat anti korosi yang sangat baik, kuat, ringan, dan sifat mampu las yang cukup bagus. Salah satu jenis aluminium yang digunakan dalam dunia industri adalah aluminium tipe AA 6061 untuk material fitting pesawat terbang, kopling, perangkat keras marinir, konektor listrik, komponen magneto, piston rem, piston hodrolik, dan lain-lain.

Metode pengelasan gesek (friction welding) ini biasanya dilakukan pada mesin-mesin perkakas seperti mesin bubut dan frais baik yang konvensional maupun CNC (computer numerical control) dan pada pengelasan FSW ini dilakukan di mesin milling vertikal. Proses pengelasan FSW banyak dilakukan di mesin perkakas milling sehingga beberapa parameter permesinan yang menjadi parameter pengelasan dalam proses ini akan memberikan pengaruh terhadap sifat mekanis hasil pengelasan (Kumar, 2011).

Dengan dengan adanya variasi besar putaran tool dan feed rate pada metode FSW dapat memberikan pengaruh yang signifikan terhadap sifat mekanis hasil pengelasan bahan Polymer HPDE (Saikh, 2010). Parameter pengelasan FSW meliputi kecepatan putar, kemiringan tool, feed rate, penetrasi shoulder, penetrasi pin, bentuk dan dimensi pin, bentuk dan dimensi shoulder, material tool (Haqqi dan Dony Setyawan, 2012). Dari beberapa penelitian yang telah disebutkan didapatkan bahwa putaran tool, feed rate, dan bentuk pintool, dimensi shoulder, material tool sangat berpengaruh terhadap sifat mekanis hasil pengelasan friction stir welding.

Proses penyambungan alumunium pada umumnya menggunakan metode pengelasan TIG, MIG dan las gas. Sejauh ini masih jarang ditemukan pengelasan material aluminium alloy AA 6061 menggunakan metode penyambungan FSW. Begitu juga dengan keterangan mengenai sifat mekanis yang dihasilkan dan hubungannya dengan variasi parameter pengelasan yang diberikan pada proses pengelasan tersebut.

Friction stir welding merupakan teknik pengelasan menggunakan sebuah tool berupa cylindrical shoulder dan pin dan dibenamkan diantara dua buah pelat logam yang akan disambung. Pada las FSW, pelat disambung dari sumber panas hasil gesekan antara perkakas las yang berputar dan permukaan pelat (Sonawan dan Rochim Suratman, 2012). Dua parameter itu digerakkan bersama-sama untuk menjaga temperature pada titik pengelasan. Logam dasar dipanaskan dengan gesekan tool hingga temperaturnya mencapai $80 \%$ dari titik leburnya sehingga menjadi lembut dan mudah disambung (Jarot Wijayanto, 2012).

Perkembangan ilmu pengelasan metode gesek mulai diciptakan dan dipatenkan pada tahun 1991 bertempat di The Welding Institute (TWI) Amerika Serikat oleh Wayne Thomas, dan sekarang ada lebih dari 135 pemegang lisensi dari pengelasan teknik FSW dengan teknik-teknik baru dan aplikasi yang terus dikembangkan setiap hari. Pengelasan metode FSW dapat digunakan untuk menyambungkan logam padat yang sejenis (similar metal) ataupun yang tidak sejenis (dissimilar metal) seperti baja biasa dengan baja tahan karat, alumunium dengan aluminium, dll. (Anwarie dkk, 2015). Adapun pemamfaatan las FSW digunakan di industri ruang angkasa, kendaraan, dan pesawat militer, produsen pesawat penerbangan sipil seperti Boeing, Airbus, dan Embraer untuk meyambung komponen seperti panel lantai, panel pesawat, dan tulang rusuk sayap (Viliam Sinkha, 2014)

Kelebihan pada proses pengelasan ini ialah tidak memerlukan bahan tambah atau bahan input energi yang rendah sehingga lebih ekonomis. Adapun kekurangan proses iniialah tool yang digunakan rawan mengalami kerusakan 
193 Muhammad Arsyad Suyuti, Luther Sonda, Misdar, Raichard Pasau, Analisis Tegangan Tarik dan Lentur Sambungan Aluminium AA 6061 Hasil Pengelasan Friction Stir Welding (FSW) Menggunakan Pin Shoulder Tool Persegi Empat karena beroperasi pada temperatur yang cukup tinggi oleh sebab itu diharuskan menggunakan tool dari material yang kuat dan tahan panas.

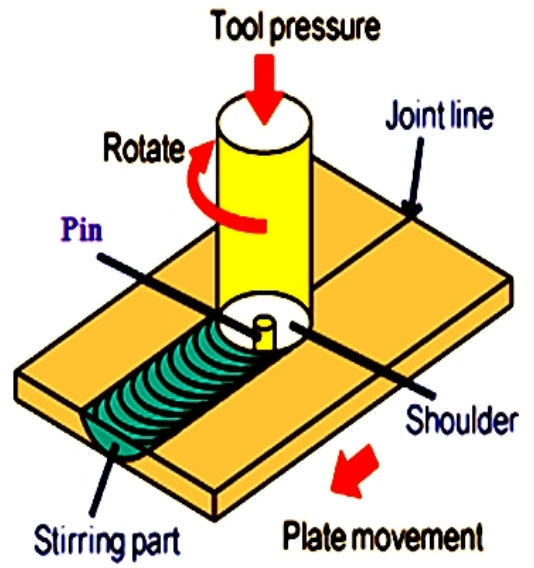

Gambar 1. Skema pengelasan FSW

Dalam penelitian ini hasil proses pengelasan FSW yang dilakukan selanjutnya diperiksa mutu pengelasan melalui pengujian destructive test (DT) untuk mengetahui sifat mekanik dan kualitas hasil pengelasan sesuai dengan variasi parameter pengelasan. Pengujian DT yang dilakukan yaitu uji tegangan tarik maksimum dan tegangan lentur.

Tegangan tarik maksimm merupakan besar beban maksimun dibagi dengan luas penampang lintang awal benda uji.

$$
\sigma_{u}=\frac{F_{u}}{A_{o}}
$$

Dimana : $\sigma_{\mathrm{u}}=$ Tegangan tarik maksimum $\left(\mathrm{N} / \mathrm{mm}^{2}\right), \mathrm{F}_{\mathrm{u}}=$ beban maksimum $(\mathrm{N})$ dan $\mathrm{A}_{0}=$ luas penampang mula-mula $\left(\mathrm{mm}^{2}\right)$

Dalam proses pengujian tegangan tarik benda uji pada saat mengalami pembebanan akan terjadi pula perpanjangan benda uji sampai putus yang disebut regangan atau elongasi (\%). Regangan atau elongasi benda uji ditentukan dengan rumus berikut ini:

$$
e=\frac{(L i-L o}{L o} \times 100 \%
$$

Dimana: $\mathrm{e}=$ regangan $(\%), \mathrm{L}_{\mathrm{o}}=$ Panjang mula - mula $(\mathrm{mm}), \mathrm{L}_{\mathrm{i}}=$ Panjang setelah putus/break (mm).

Hasil dari pengujian ini berupa nilai tegangan dan regangan yang digambarkan dalam sebuah kurva uji tarik. 


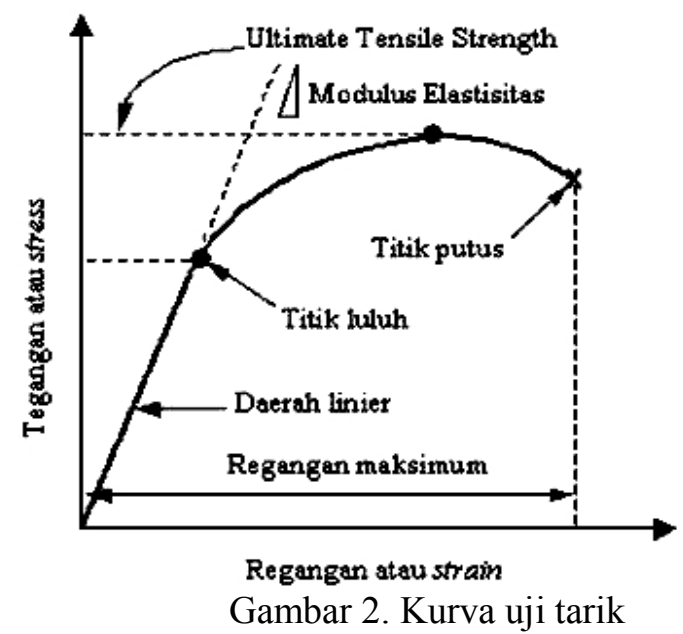

Pengujian tegangan lentur adalah salah satu cara pengujian sifat mekanis bahan yang menerima pembebanan terhadap suatu bahan pada satu titik tengah dari bahan yang ditahan diatas dua tumpuan yang menyebabkan lenturan atau tekukan terhadap bahan yang ditekan. Momen tekuk yang bekerja selalu tegak lurus terhadap arah sumbu pada bahan sehingga menyebabkan tegangan tekuk pada bahan yang di uji.

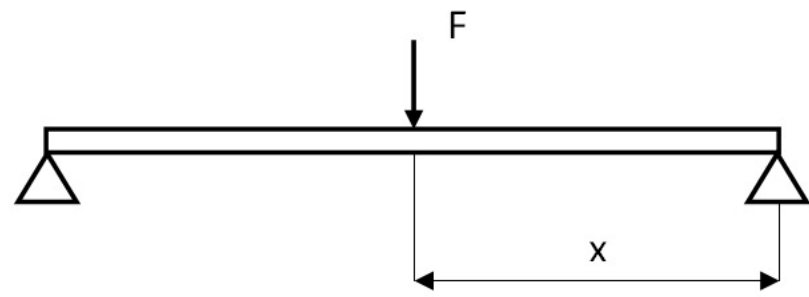

Gambar 3. Momen bending pada bahan

Tegangan lentur dapat dihitung dengan menggunakan persamaan persamaan:

$$
\sigma b=\frac{M}{W}
$$

Dimana, $\sigma_{\mathrm{b}}=$ Tegangan lentur $(\mathrm{MPa}) ; \mathrm{M}=$ Momen lentur $(\mathrm{N} . \mathrm{mm})$ dan $\mathrm{W}=$ Momen tahanan lentur $\left(\mathrm{mm}^{3}\right)$. Pengujian tegangan lentur dilakukan dengan metode tranversal Bending. Pada transversal bending ini, pengambilan spesimen tegak lurus dengan arah pengelasan. Berdasarkan arah pembebanan dan lokasi pengamatan, pengujian transversal bending yang dilakukan adalah Face bend (bending permukaan las) dan Root bend (bending pada akar las).

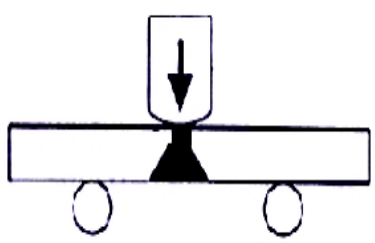

(a)

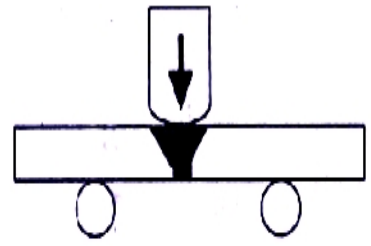

(b)

Gambar 4. (a) Face bending dan (b) Root bending 
195 Muhammad Arsyad Suyuti, Luther Sonda, Misdar, Raichard Pasau, Analisis Tegangan Tarik dan Lentur Sambungan Aluminium AA 6061 Hasil Pengelasan Friction Stir Welding (FSW) Menggunakan Pin Shoulder Tool Persegi Empat

\section{METODE PENELITIAN}

Eksperimen penelitian ini dilaksanakan pada bengkel Mekanik, Laboratorium Mekanik Politeknik Negeri Ujung Pandang. Material yang digunakan dalam penelitian ini adalah baja EMS 45 sebagai tool dan Aluminium Alloy AA 6061 sebagai material dasar logam induk. Adapun komposisi kimia logam induk aluminium AA 6061 dapat dilihat pada tabel berikut:

Tabel 1. Komposisi kimia aluminium AA 6061

\begin{tabular}{|c|c|c|c|c|c|c|c|c|c|c|}
\hline \multicolumn{10}{|c|}{ Komposisi kimia (\%) } \\
\hline Elemen & $\mathrm{Si}$ & $\mathrm{Fe}$ & $\mathrm{Cu}$ & $\mathrm{Mn}$ & $\mathrm{Mg}$ & $\mathrm{Cr}$ & $\mathrm{Ni}$ & $\mathrm{Zn}$ & $\mathrm{Ti}$ & $\mathrm{Zr}$ \\
\hline Nilai & 0,721 & 0,324 & 0,222 & 0,077 & 1,080 & 0,065 & 0,004 & 0,116 & 0,065 & - \\
\hline
\end{tabular}

Sedangkan sifat mekanis material aluminium AA 6061 berdasarkan perhitungan hasiluji tarik dan uji lentur yang dilakukan pada laboratorium didapatkan nilai seperti pada tabel 2 berikut:

Tabel 2. Sifat mekanis material logam induk aluminium AA 6061

\begin{tabular}{|l|c|}
\hline \multicolumn{2}{|c|}{ Sifat mekanis aluminium AA 6061} \\
\hline Kekuatan tarik $\left(\sigma_{\mathrm{u}}\right)$ & $327.1 \mathrm{MPa}$ \\
\hline Regangan $(\varepsilon)$ & $13.5 \%$ \\
\hline Kekuatan Lentur $\left(\sigma_{\mathrm{b}}\right)$ & $578.14 \mathrm{MPa}$ \\
\hline
\end{tabular}

Sedangkan bahan tool yang digunakan adalah baja bohler EMS 45 dengan komposisi kimia sebagai berikut:

Tabel 3. Komposisi kimia baja EMS 45

\begin{tabular}{|l|c|c|c|c|c|c|c|c|}
\hline \multicolumn{10}{|c|}{ Komposisi Kimia (\%) } \\
\hline Elemen & $\mathrm{C}$ & $\mathrm{Si}$ & $\mathrm{Mn}$ & $\mathrm{Cr}$ & $\mathrm{Mo}$ & $\mathrm{Ni}$ & $\mathrm{V}$ & $\mathrm{W}$ \\
\hline Nilai & 0,48 & 0,30 & 0,70 & - & - & - & - & - \\
\hline
\end{tabular}

Proses friction stir welding dalam eksprimen ini dikerjakan pada mesin milling vertikal menggunakan sebuah tool dengan pin berbentuk persegi empat. Sedangkan benda kerja yang disambung ialah alumunium alloy AA 6061. Benda kerja terlebih dahulu dipotong dan diratakan sisi-sisinyanya sehingga bisa terjepit dengan baik pada meja mesin dengan menggunakan ragum dan clamp set. Setelah tool terpasang dan logam induk Aluminium AA 6061 sudah dijepit pada meja mesin maka selanjutnya tool diputar dan melakukan pentrasi ke logam induk kemudian tool digerakkan dengan kecepatan konstan sesuai parameter pengelasan yang akan diberikan. Dalam eksperimen terlebih dahulu dilakukan percobaan awal guna memperoleh parameter putaran tool dan feeding yang tepat untuk digunakan dalam menyambung pengelasan FSW ini . Parameter pengelasan FSW yang dapat diterima dalam eksprimen ini dapat dilihat pada tabel 4. berikut:

Tabel 4. Parameter Pengelasan

\begin{tabular}{|l|c|c|c|}
\hline \multirow{2}{*}{ Parameter Pengelasan } & \multicolumn{3}{|c|}{ Variasi } \\
\cline { 2 - 4 } & Rendah & Sedang & Tinggi \\
\hline Putaran $(\mathrm{rpm})$ & 1300 & 1950 & 2850 \\
\hline Feeding $(\mathrm{mm} / \mathrm{min})$ & 45 & 90 & 135 \\
\hline
\end{tabular}


Adapun ukuran tool yang digunakan: sisi-sisi pin $6 \mathrm{~mm}$, panjang pin 4.8 $\mathrm{mm}$, dan diameter shoulder $22 \mathrm{~mm}$. Sedangkan ukuran logam induk alumunium alloy AA 6061 dengan tebal $5 \mathrm{~mm}$, lebar $75 \mathrm{~mm}$, panjang $150 \mathrm{~mm}$. Proses dan hasil pengelasan FSW dapat dilihat pada gambar 5 dan 6 berikut ini:

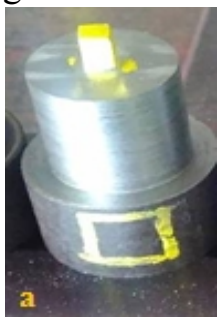

(a)

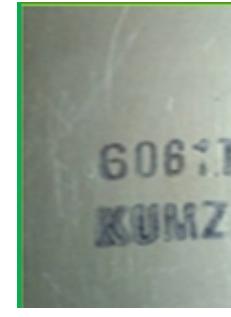

(b)

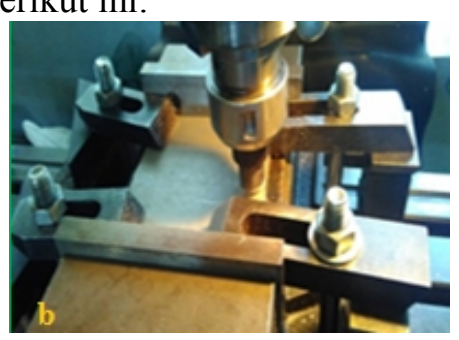

(c)

Gambar 5. Proses FSW: (a) Tool persegi empat (b) Aluminium AA 6061 (c). FSW

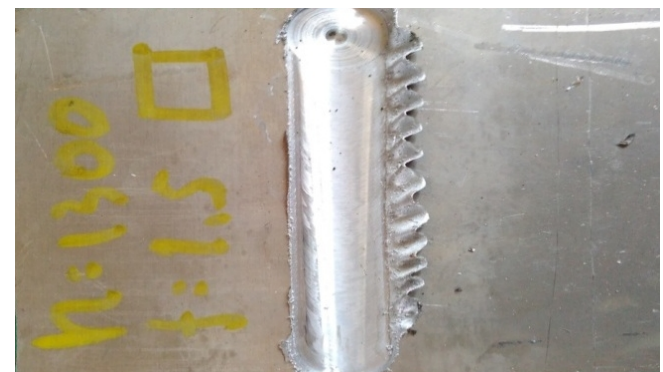

Gambar 6. Hasil pengelasan FSW aluminium AA 6061

Setelah proses pengelasan FSW selesai selanjutnya dibentuk spesimen uji tarik dan lentur kemudian dilanjutkan denganuji tari dan uji lentur seperti ditunjukkan pada gambar 7 berikut:

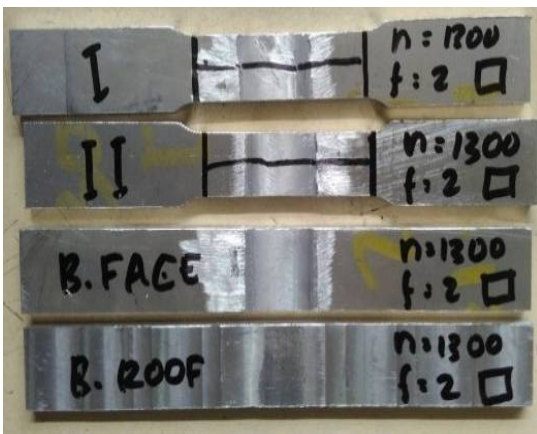

(a)

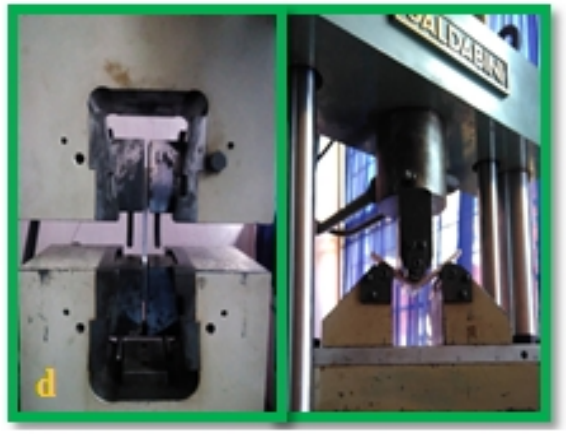

(b)

Gambar 7. (a) Spesimen uji tarik dan uji lentur (b) proses pengujian tarik dan lentur

\section{HASIL DAN PEMBAHASAN}

\section{A. Tegangan tarik maksimum}

Hasil pengelasan FSW Aluminium AA 6061 diuji dengan menggunakan Universal Testing Machine (UTM) untuk mengetahui tegangan tarik maksimum $(\mathrm{MPa})$, regangan dan sambungan pengelasan tersebut. Dalam pengujian ini 
197 Muhammad Arsyad Suyuti, Luther Sonda, Misdar, Raichard Pasau, Analisis Tegangan Tarik dan Lentur Sambungan Aluminium AA 6061 Hasil Pengelasan Friction Stir Welding (FSW) Menggunakan Pin Shoulder Tool Persegi Empat diperoleh tegangan tarik maksimum dan regangan sambungan hasil FSW. Adapun tegangan tarik pengelasan FSW sambungan material alumunium AA 6061 dari hasil pengujian dapat ditunjukkan pada tabel 5 berikut ini:

Tabel 5. Tegangan tarik maksimum $\left(\sigma_{\mathrm{u}}\right)$ hasil sambungan FSW dan logam induk

\begin{tabular}{|c|c|c|c|c|}
\hline $\begin{array}{c}\text { Putaran } \\
(\mathrm{rpm})\end{array}$ & $\begin{array}{c}\text { Feeding } \\
(\mathrm{mm} / \mathrm{min})\end{array}$ & $\begin{array}{c}\sigma_{\mathrm{u}} \text { Hasil FSW } \\
(\mathrm{MPa})\end{array}$ & $\begin{array}{c}\sigma_{\mathrm{u}} \text { Logam induk } \\
(\mathrm{MPa})\end{array}$ & $\begin{array}{c}\text { Persentase } \sigma_{\mathrm{u}} \text { FSW dari } \\
\text { logam induk }(\%)\end{array}$ \\
\hline \multirow{3}{*}{1300} & 45 & 158.25 & 327.17 & 48.37 \\
\cline { 2 - 5 } & 90 & 160.93 & 327.17 & 49.19 \\
\hline \multirow{3}{*}{1950} & 135 & 146.27 & 327.17 & 44.71 \\
\cline { 2 - 5 } & 45 & 139.97 & 327.17 & 42.78 \\
\hline \multirow{3}{*}{2850} & 90 & 98.37 & 327.17 & 30.07 \\
\cline { 2 - 5 } & 135 & 126.15 & 327.17 & 33.56 \\
\hline & 45 & 109.50 & 327.17 & 40.16 \\
\hline
\end{tabular}

Berdasarkan tabel 5 maka diperoleh grafik pada gambar 9 berikut ini:

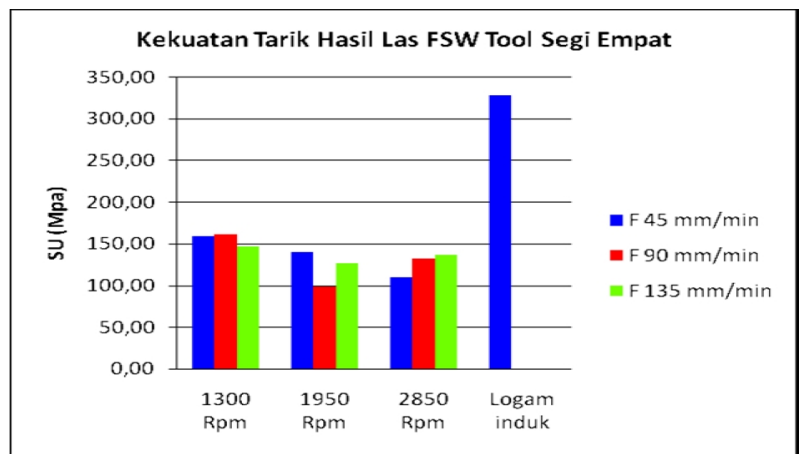

Gambar 9. Grafik kekuatan tarik hasil FSW bentuk pin persegi empat

Dari tabel 5 dan gambar 9. tersebut diatas memperlihatkan bahwa proses pengelasan menggunakan beberapa variasi parameter pengelasan. Untuk parameter putaran terdiri dari 3 variasi yaitu putaran $1300 \mathrm{rpm}, 1950 \mathrm{rpm}$ dan $2850 \mathrm{rpm}$. Sedangkan parameter feeding juga menggunakan 3 variasi yaitu $45 \mathrm{~mm} / \mathrm{min}, 90$ $\mathrm{mm} / \mathrm{min}$ dan $135 \mathrm{~mm} / \mathrm{min}$. Dalam grafik tersebut juga ditunjukkan tegangan tarik maksimum logam induk.

Pada tabel 5. dan gambar 9 tersebut juga memperlihatkan bahwa tegangan tarik maksimum dari tertinggi ke terendah pada tiga variasi putaran didapatkan pada variasi putaran $1300 \mathrm{Rpm}$ dengan tegangan tarik maksimum tertinggi diperoleh sebesar 160,93 MPa pada feeding $90 \mathrm{~mm} / \mathrm{min}$ dengan regangan sebesar $3.2 \%$. Selanjutnya putaran 1950 diperoleh tegangan tarik maksimum tertinggi sebesar $139.97 \mathrm{MPa}$ pada feeding $45 \mathrm{~mm} / \mathrm{min}$ dengan regangan sebesar $2.5 \%$. Sedangkan terendah pada putaran putaran $2850 \mathrm{Rpm}$ tegangan tarik tertinggi terdapat pada feeding $135 \mathrm{~mm} / \mathrm{min}$ sebesar $136.66 \mathrm{MPa}$ dengan regangan sebesar $2.3 \%$. Sedangkan tegangan tarik maksimum terendah dari keseluruhan parameter pengelasan diperoleh pada putaran $1950 \mathrm{Rpm}$ pada feeding $90 \mathrm{~mm} / \mathrm{min}$ dengan tegangan tarik maksimum sebesar 98.37 MPa dengan regangan sebesar $1.6 \%$.

Meskipun hasil eksprimen FSW telah berhasil tersambung dengan baik, namum secara umum dari tabel 5 dan grafik pada gambar 9 memperlihatkan bahwa tegangan tarik maksimum hasil penyambungan FSW pada semua variasi putaran dan feeding yang dilakukan masih lebih rendah dibanding dengan tegangan tarik maksimum logam induk. Hal ini menunjukkan bahwa patahan terjadi pada daerah 
Nugget Zone atau Thermomechaniically Affected Zone (TMAZ). Dimana tegangan tarik maksimum terbaik diperoleh pada putaran rendah $1300 \mathrm{rpm}$ pada semua variasi feeding dengan tegangan tarik antara $146.27 \mathrm{MPa}$ s/d $160.93 \mathrm{MPa}$. Sedangkan kekuatan tarik pada Nugget Zone dan Thermomechaniically Affected Zone (TMAZ) terhadap kekuatan tarik logam induk masih jauh lebih rendah yaitu 44.71 s.d 49.19 untuk putaran $1300 \mathrm{rpm}, 30.07$ s.d $42.78 \%$ untuk putaran 1950 rpm dan $33.47 \%$ s.d $41.77 \%$ untuk putaran $2850 \mathrm{rpm}$.

\section{B. Tegangan lentur}

Pelengkungan (bending) merupakan proses pembebanan terhadap suatu bahan pada suatu titik ditengah-tengah dari bahan yang ditahan diatas dua tumpuan. Dengan pembebanan ini bahan akan mengalami deformasi dengan dua buah gaya yang berlawanan bekerja pada saat yang bersamaan. Pada saat batang uji diberi beban sampai sebelum batang uji itu patah maka akan terjadi tegangan pada batang uji. Tegangan yang terjadi disebut dengan tegangan lentur. Dalam pengujian kekuatan lentur dilakukan pada dua sisi yaitu sisi face bending dan sisi root bending seperti ditunjukkan berikut ini:

\section{Tegangan lentur dengan face bending}

Tegangan lentur dengan face banding pada sambungan pengelasan FSW material alumunium AA 6061 dengan variasi putaran dan feeding dapat dilihat pada tabel 5 dan grafik 10 berikut ini:

Tabel 6. Tegangan lentur face bend hasil sambungan FSW dan logam induk

\begin{tabular}{|c|c|c|c|c|}
\hline $\begin{array}{c}\text { Putaran } \\
(\mathrm{rpm})\end{array}$ & $\begin{array}{c}\text { Feeding } \\
(\mathrm{mm} / \mathrm{min})\end{array}$ & $\begin{array}{c}\text { Tegangan lentur } \\
\text { hasil FSW (MPa) }\end{array}$ & $\begin{array}{c}\text { Tegangan lentur } \\
\text { logam induk (MPa) }\end{array}$ & $\begin{array}{c}\text { Persentase } \sigma_{\mathrm{u}} \text { FSW dari } \\
\text { logam induk (\%) }\end{array}$ \\
\hline \multirow{3}{*}{1300} & 45 & 309.94 & 578.18 & 53.61 \\
\cline { 2 - 5 } & 90 & 456.38 & 578.18 & 78.93 \\
\cline { 2 - 5 } & 135 & 298.94 & 578.18 & 51.70 \\
\hline \multirow{3}{*}{1950} & 45 & 146.75 & 578.18 & 25.38 \\
\cline { 2 - 5 } & 90 & 161.11 & 578.18 & 27.87 \\
\cline { 2 - 5 } & 135 & 177.23 & 578.18 & 30.65 \\
\hline \multirow{3}{*}{2850} & 45 & 103.11 & 578.18 & 17.83 \\
\cline { 2 - 5 } & 90 & 160.35 & 578.18 & 27.73 \\
\cline { 2 - 5 } & 135 & 186.32 & 578.18 & 32.22 \\
\hline
\end{tabular}

Berdasarkan tabel 6 tersebut diatas maka diperoleh tabel tegangan lentur seperti pada gambar 10 berikut ini:

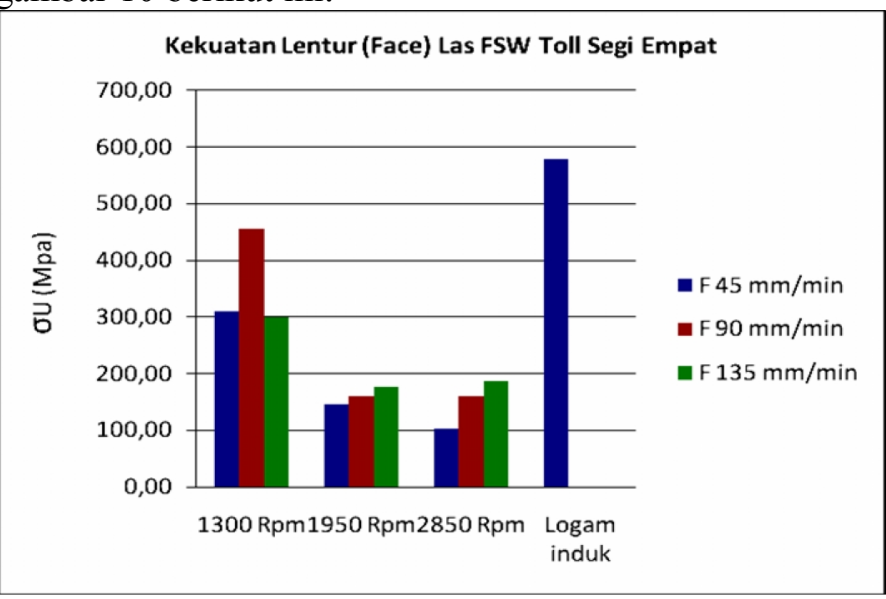

Gambar 10. Diagram tegangan lentur (face bend) hasil FSW tool persegi empat 
199 Muhammad Arsyad Suyuti, Luther Sonda, Misdar, Raichard Pasau, Analisis Tegangan Tarik dan Lentur Sambungan Aluminium AA 6061 Hasil Pengelasan Friction Stir Welding (FSW) Menggunakan Pin Shoulder Tool Persegi Empat

Pada pengujian lentur dengan face bend ini dikerjakan pada jarak tumpuan $80 \mathrm{~mm}$ dan sudut tekukan $180^{\circ}$. Dari hasil pengujian menunjukan masih terdapat beberapa sampel yang mengalami keretakan/patah pada bagian logam las. Dengan tiga variasi putaran dan feeding yang diberikan, putaran $1300 \mathrm{rpm}$ dengan feeding $90 \mathrm{~mm} / \mathrm{min}$ memiliki nilai tegangan lentur tertinggi sebesar 456.38 MPa dengan tidak terjadi perpatahan di logam las dan terendah terdapat pada feeding 135 $\mathrm{mm} / \mathrm{min}$ sebesar 298,94 MPa dimana terjadi perpatahan di logam las. Kemudian putaran $1950 \mathrm{Rpm}$ nilai tegangan lentur tertinggi terdapat pada feeding 135 $\mathrm{mm} / \mathrm{min}$ sebesar $177.23 \mathrm{MPa}$ dengan terjadi perpatahan di logam las dan terendah terdapat pada feeding $45 \mathrm{~mm} / \mathrm{min}$ sebesar $146.75 \mathrm{MPa}$ dengan terjadi perpatahan di logam las. Untuk putaran $2850 \mathrm{rpm}$ memiliki nilai tegangan lentur tertinggi terdapat pada feeding $135 \mathrm{~mm} / \mathrm{min}$ sebesar $186.32 \mathrm{MPa}$ dengan terjadi perpatahan di logam las dan terendah terdapat pada feeding $45 \mathrm{~mm} / \mathrm{min}$ sebesar $103.11 \mathrm{MPa}$ dengan perpatahan terjadi di logam las.

Jadi dapat diambil kesimpulan untuk tool persegi empat bahwa putaran $1300 \mathrm{Rpm}$ dengan feeding $90 \mathrm{~mm} / \mathrm{min}$ memiliki nilai tegangan lentur terbesar, karena dapat menahan beban reaksi tumpuan yang lebih besar terhadap gaya yang diberikan, dibandingkan dengan putaran 1950 Rpm dan 2850 Rpm serta tidak mengalami retakan/patahan saat mengalami beban lentur.

Persentase tegangan lentur hasil sambungan FSW jauh lebih rendah dari tegangan lentur logam induk yaitu sekitar 51.70 s.d $78.93 \%$ pada putaran 1300 rpm, 25.38 s.d 30.65 pada putaran $1950 \mathrm{rpm}$ dan 17.83 s.d $32.22 \%$ pada putaran $2850 \mathrm{rpm}$.

\section{Tegangan lentur dengan root bending}

Sedangkan tegangan lentur untuk root banding pada sambungan pengelasan FSW material alumunium AA 6061 dengan variasi putaran dan feeding dapat dilihat pada tabel 6 dan berikut ini:

Tabel 6. Tegangan lentur root bending hasil sambungan FSW dan logam induk

\begin{tabular}{|c|c|c|c|c|}
\hline $\begin{array}{c}\text { Putaran } \\
(\mathrm{rpm})\end{array}$ & $\begin{array}{c}\text { Feeding } \\
(\mathrm{mm} / \mathrm{min})\end{array}$ & $\begin{array}{c}\text { Tegangan lentur } \\
\text { hasil FSW (MPa) }\end{array}$ & $\begin{array}{c}\text { Tegangan lentur } \\
\text { logam induk (MPa) }\end{array}$ & $\begin{array}{c}\text { Persentase } \sigma_{\mathrm{u}} \text { FSW } \\
\text { dari logam induk (\%) }\end{array}$ \\
\hline \multirow{3}{*}{1300} & 45 & 432.28 & 578.18 & 74.77 \\
\cline { 2 - 5 } & 90 & 431.71 & 578.18 & 74.67 \\
\hline \multirow{3}{*}{1950} & 135 & 487.22 & 578.18 & 84.27 \\
\cline { 2 - 5 } & 45 & 326.11 & 578.18 & 56.40 \\
\hline \multirow{3}{*}{2850} & 135 & 232.00 & 578.18 & 60.13 \\
\cline { 2 - 5 } & 45 & 380.47 & 578.18 & 55.80 \\
\hline & 135 & 322.22 & 578.18 & 58.67 \\
\hline
\end{tabular}

Berdasarkan tabel 6 tersebut diatas maka diperoleh tabel tegangan lentur seperti pada gambar 11 berikut ini: 


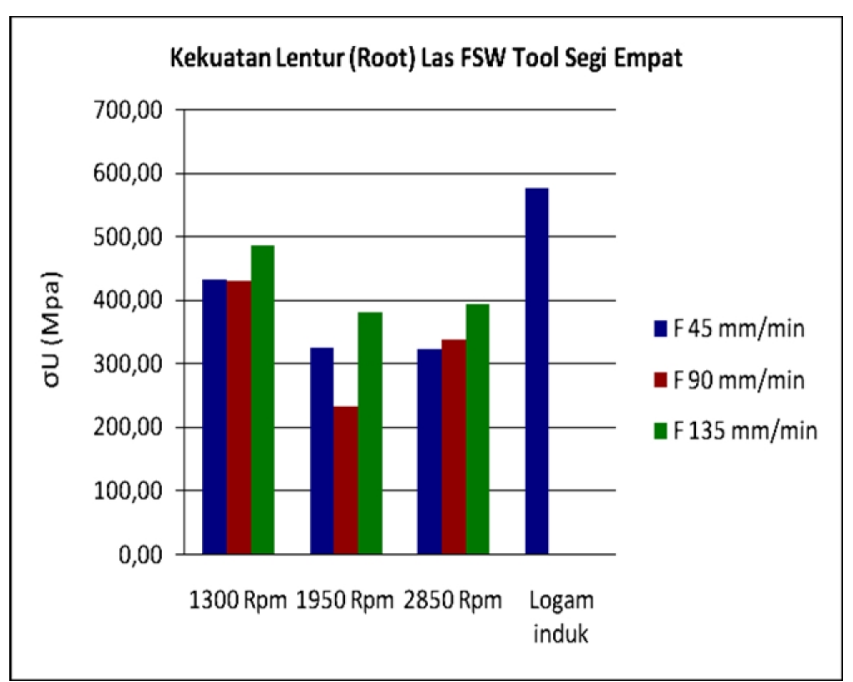

Gambar 11. Diagram kekuatan lentur root bending hasil las FSW tool persegi empat

Pada pengujian lentur dengan root bend yang dilakukan dengan jarak tumpuan $80 \mathrm{~mm}$ dan sudut tekukan $180^{\circ}$, menunjukan semua spesimen yang telah diuji ada yang mengalami dan tidak mengalami keretakan/patah pada bagian logam las. Dengan tiga variasi putaran dan feeding yang diberikan, putaran 1300 Rpm dengan feeding $135 \mathrm{~mm} /$ min memiliki nilai tegangan lentur tertinggi sebesar 487.22 MPa dengan tidak terjadi perpatahan di logam las dan terendah terdapat pada feeding $90 \mathrm{~mm} / \mathrm{min}$ sebesar $431.71 \mathrm{MPa}$ dengan tidak terjadi perpatahan di logam las. Kemudian putaran $1950 \mathrm{Rpm}$ nilai tegangan lentur tertinggi terdapat pada feeding $135 \mathrm{~mm} / \mathrm{min}$ sebesar $380.47 \mathrm{MPa}$ dengan tidak terjadi perpatahan di logam las dan terendah terdapat pada feeding $90 \mathrm{~mm} / \mathrm{min}$ sebesar $232 \mathrm{MPa}$ dengan terjadi perpatahan di logam las. Untuk putaran $2850 \mathrm{rpm}$ memiliki nilai tegangan lentur tertinggi terdapat pada feeding $135 \mathrm{~mm} / \mathrm{min}$ sebesar $\quad 394.71 \mathrm{MPa}$ dengan tidak terjadi perpatahan di logam las dan terendah terdapat pada feeding 45 $\mathrm{mm} /$ min sebesar $322.22 \mathrm{MPa}$ dengan tidak terjadi perpatahan di logam las. Jadi, dapat diambil kesimpulan bahwa untuk tool persegi empat putaran $1300 \mathrm{rpm}$ dengan feeding $135 \mathrm{~mm} / \mathrm{min}$ memiliki nilai tegangan lentur terbesar, karena dapat menahan beban reaksi tumpuan yang lebih besar terhadap gaya yang diberikan dibandingkan dengan putaran $1950 \mathrm{rpm}$ dan $2850 \mathrm{rpm}$.

Kekuatan lentur yang berbeda pada setiap putarandan feeding disebabkan karena perpaduan antaraputaran dan feeding sangat berpengaruh terhadap besarnya panas yang dihasilkan terehadap spesimen las. Adapun nilai kekuatan lentur spesimen hasil las yang semuanya lebih kecil dari logam induk disebabkan karena terbentuknya penyambungan yang tidak optimal saat proses pengelasan.

\section{KESIMPULAN}

Berdasarkan penelitian yang telah dilakukan disimpulkan bahwa pada pengelasan friction stir welding (FSW) kualitas sambungan aluminium AA 6061 yang dihasilkan pada semua variasi putaran dan feeding dengan menggunakan pin shoulder tool berbentuk persegi empat mengalami penurunan tegangan tarik maksimum dan tegangan lentur yang sangat signifikan, jika dibandingkan dengan logam induknya. Secara umum kualitas tegangan tarik dan tegangan lentur yang 
201 Muhammad Arsyad Suyuti, Luther Sonda, Misdar, Raichard Pasau, Analisis Tegangan Tarik dan Lentur Sambungan Aluminium AA 6061 Hasil Pengelasan Friction Stir Welding (FSW) Menggunakan Pin Shoulder Tool Persegi Empat

terbaik terdapat pada putaran rendah yaitu $1300 \mathrm{rpm}$ pada semua variasi feeding. Sedangkan tegangan tarik tertinggi diperoleh pada putaran 1300 dan feeding 90 $\mathrm{mm} /$ min dengan tegangan tarik tertinggi sebesar $160.93 \mathrm{MPa}$ sedangkan tegangan lentur terbesar diperoleh pada root bending putaran $1300 \mathrm{rpm}$ dengan feeding 135 $\mathrm{mm} / \mathrm{min}$ sebesar 487.22 MPa.

\section{DAFTAR PUSTAKA}

Anwarie, Rifko dkk. 2015. Studi Komparatif Hasil Friction Stir Welding (FSW) dan Gas Tungsten Arc Welding (GTAW) Pada Sambungan Las Aluminium Seri 5083. Prosiding Skf.

Danial, Ahmad. 2012. Mechanical Properties of Dissimilar Alumunium-Based Alloy Joints by MIG Welding. Thesis. Malaysia: Universitas Malaysia Pahang.

Haqqi, Syaifuldan Dony Setyawan. 2012. Analisis Pengaruh Backing Plate Material Pengelasan Dua Sisi Friction Stir Welding Terhadap Sifat Mekanis Aluminium 5083 Pada Kapal Katamaran. Jurnal teknik pomits vol.1,no. 2.

Kumar. 2011. A Study of Process Parameters of Friction Stir Welded AA 6061 Alloy in $\mathrm{O}$ and T6 Conditions. ARPN Journal of Engineering and Applied Sciences, 12(15).

Nicholas, E et al. 2000. Friction Stir Welding-A Decade On. IIW Asian Pacific Welding Congress, 1 (16)

Pamungkas, Angger Sudrajat F. dkk.2012. Analisis Sifat Mekanis Hasil Pengelasan Aluminium AA 1100 Dengan Metode Friction Stir Welding (FSW). Jurnal ROTOR Volume 5 Nomor 1.

Pradeep, A. and Muthukumaran. 2013. An Analysis to Optimize The Process Parameters of Friction Stir Welded Low Alloy steel Plates. International Journal of Engineering, Science and Technology, 5(3).

Rusdi Nur, Muhammad Arsyad Suyuti and Ahmad Zubair S. 2016. Mechanical Properties on Friction Stir Welding of Aluminium Alloy 5052, Journal of Engineering and Applied Sciences ARPN, 6(2).

Rajiv S. Mishra, Murray W. Mahoney. 2007. Friction Stir Welding and Processing, ASM International. Ohio. United States of America.

Shaikh. 2014. Effect of Friction Stir Welding Process Parameters on Polymer Weld. International Journal for Technology Research in Engineering, $1(9)$.

Sidhu, Mandep Singh and Sukhpal Singh Chatha. 2012. Friction Stir WeldingProcess and its Variables: A Review. India: Punjabi University Campus. 
Sinkha, Villiam. 2014. The Present And Future Prospects Of Friction Stir Welding In Aeronautics. Brasil: Universidade do Vale do Paraíba, FEAU, São José dos Campos.

Sunawan, Rochim Suratman. 2003. Pengantar Untuk Memahami Proses Pengelasan Logam. Bandung: Alfabeta.

Wijayanto, Jarot. 2012. Pengaruh Feed Rate Terhadap Sifat Mekanis Pada Friction Stir Welding Alumunium. Prosiding Seminar Nasional Aplikasi Sains \& Teknologi (SNAST) Periode III Yogyakarta. 